\title{
COVID-19 Has Changed the Course of Education Around the World
}

\author{
Hasanova.J.V.* Najafova.K.A. Kerimova M.V. \\ Azerbaijan State University of Economics - UNEC, Baku, Azerbaijan \\ "Corresponding author. Email: cemile.hasanova@unec.edu.az,
}

\begin{abstract}
The authors of the article focused on the World Economic Forum: COVID-19 has become a catalyst for educational institutions around the world.

The World Economic Forum notes that the coronavirus (COVID-19) has changed the course of education around the world in a matter of weeks. These changes give us insight into how education can change for better or worse in the long run. More than a quarter of a billion children worldwide are denied access to education. Millions of others are discriminated against in education, the UNESCO report says.

The United Nations Educational, Scientific and Cultural Organization (UNESCO) has criticized discrimination against millions of children in education around the world. More than a quarter of a billion children and adolescents have no access to education at all, while millions of others face discrimination because of their origin, personality, or disability, according to the UN report "Integration and Education: Means to All for All".
\end{abstract}

Keywords: covid-19, digitalization, educational interaction, Internet resource, online courses, higher

education

\section{INTRODUCTION}

With the rapid spread of the coronavirus in Asia, Europe, the Middle East, and the United States, countries have taken swift and decisive action to mitigate the impact of the full-blown pandemic. Over the past two weeks, several statements have been made about the suspension of classes in schools and universities. The Organization for Economic Co-operation and Development estimates that as of March 13, more than 421 million children are suffering from school closings announced or commissioned in 39 countries. 22 other countries said they had switched to a partially "localized" regime.

These risk management solutions have led millions of students to a temporary homeschooling situation, especially in the countries hardest hit by the coronavirus such as China, Korea, Italy, and Iran. These changes have caused some concern and led to new examples of innovation in education.

Today, there is no area not affected by the consequences of the spread of COVID-19. The impact that the coronavirus pandemic has had on the higher education system is specific in different regions of the world. Nevertheless, the general vector of these changes can be traced: the pandemic has put universities in difficult conditions, forcing them to adapt to the current events in the shortest possible time, spend significant funds for accelerated digitalization, and often make decisions without considering possible consequences. The pandemic had a negative impact on international cooperation in the field of education and science: international travel was canceled, exchange programs and academic mobility of students and academic staff were suspended, and many research cooperation programs were paused.

\section{RESEARCH METHODOLOGY}

Universities were forced to solve many issues in a short time: in what format to conduct distance learning; what technical means to use for this; how to assess the assimilation of the material by students; how to conduct final exams, how to recruit students for the next academic year. The latter is relevant for countries where final exams at school have been canceled or postponed indefinitely.

The emergency transition to distance learning has led to some interrelated problems.

Some countries were unable to switch to online education for various reasons, including lack of logistics, lack of wide coverage of Internet networks, low living standards of the population, etc. For example, Latin American countries have suspended classes at universities. One of Argentina's leading universities, the University of Buenos Aires, has decided to cancel classes and change the academic calendar, rather than moving to online learning, believing that only full-time education can guarantee a high level of quality. The National Institute of Science and Technology of Zimbabwe and several other African universities have announced their closure until further notice. Malaysia's Minister of Higher Education has suspended the transition to distance learning. 
In many countries, students have organized opposition to the shift to distance learning. Strikes against the transition to the online format took place in the Philippines, demanding the termination of the contract and refund of tuition fees since distance learning is not an equivalent substitute for traditional forms of education, as well as due to a lack of necessary equipment and poor Internet access. In many African universities, student unions have opposed online learning due to the lack of the necessary conditions and technical means. In Tunisia, a student union protested the government's decision to adapt online learning during the pandemic, calling it a discriminatory measure, and called for a boycott of online platforms. In Chile, students from the country's leading public institution, the University of Chile, and the private University of San Sebastian, have initiated online strikes. In the UK, more than 300,000 students have signed a petition demanding reimbursement of their tuition fees.

There is a significant decrease in the quality of education during the transition to distance learning in the absence of existing learning management systems in many countries software for the administration of training courses within the framework of distance learning. The Pakistan Higher Education Commission failed to develop a clear and understandable online learning strategy and policy for public and private universities, which created confusion among university administrators, faculty, and students.

Problems arise with online applications through which universities conduct remote lectures or seminars. Some universities have announced that they are abandoning the Zoom platform and switching to Google Meet or other applications. In connection with hacker attacks, online education at a number of leading universities was temporarily suspended. The concept of Zoombombing has emerged, characterizing actions related to the violation of online spaces, including hacking virtual classrooms, posting pornographic or hateful images, shouting offensive language, etc.

University sites work unstable due to the increased load on databases and information systems of universities.

The qualifications of employees for the transition to online learning are not enough: there is a lack of knowledge about the available platforms and services for remote learning, their functionality, effective teaching methods in online format, etc. What the majority of universities in the developing world offers does not meet the high standards of online learning and online education.

While it is too early to judge how COVID-19 will affect education globally, there are signs that innovation and digitalization could have a long-term impact on learning trajectories. Below are three trends that could indicate future developments:

Moving education towards innovation can lead to unexpected innovation.

The slow pace of change in academic institutions around the world is reflected in centuries of lecture-based institutional superstition and outdated teaching approaches. COVID-19 has become a catalyst for educational institutions around the world to find innovative solutions in a relatively short period.
To slow the spread of the virus, students in Hong Kong began homeschooling in February using interactive apps. In China, 120 million people have access to educational materials on live television programs. Other simpler but less creative solutions have been implemented all over the world. In one Nigerian school, standard asynchronous online learning tools (such as reading materials via Google Classroom) were supplemented with synchronous video instructions that helped prevent school closures.

$5 \mathrm{G}$ technology is becoming more common in countries such as China, the United States, and Japan. Students and solution providers use the concept of digital learning in a variety of formats, "learning anywhere, anytime". Traditional classroom education will be complemented by new teaching methods, from live broadcasts to educated influencers and virtual reality. Learning can become a habit built into your daily work schedule, a real way of life.

Educational partnerships between the public and private sectors can be strengthened.

Over the past few weeks, we have witnessed the formation of learning consortia and coalitions involving various stakeholders, including governments, publishers, educators, technology providers, and telecommunications network operators, to use digital platforms as a temporary solution to the crisis. Where education is primarily provided by the government, this could become a widespread trend for the future of education.

China's Ministry of Education has set up a multistakeholder group to develop a new cloud platform for cloud-based online learning and broadcasting, and to modernize the educational infrastructure complex, led by the Ministry of Education and the Ministry of Industry and Information Technology.

Likewise, the Hong Kong-based readtogether.hk forum is a consortium of over 60 educational organizations, publishers, media and entertainment professionals, providing over 900 educational resources, including videos, book chapters, assessment tools, and free consulting services. The consortium intends to continue using the platform after the localization of COVID-19.

These examples show that educational innovation receives more support than a typical social project funded by the state or non-profit organization. The digital divide can be widened. Most schools in virus-infected areas find nonstandard solutions for continuing education, but the quality of education largely depends on the level and quality of digital access. After all, only $60 \%$ of the world's population is online.

\section{RESULTS}

It is expected that research institutes and leading universities with stable income and well-known at home and abroad will quickly recover from the crisis. At the same time, a number of universities, primarily private ones, which are completely dependent on tuition fees, may close. Millions of students with financial disabilities will have to abandon higher education or opt for more 
accessible public universities. Universities with international students will also face significant challenges. The pandemic has had a negative impact on the work of higher education institutions in all countries of the world, without exception, but the poor countries, foreign students and students from socially vulnerable segments of the population, undoubtedly suffered the most.

The spread of the coronavirus could lead to 7 million school dropouts in the future.

Annette Dixon, the World Bank's vice president of human development, said the school closures affected children in many ways. The crisis will not irreparably damage the education of millions of children if a fast, decisive and coordinated plan of action is implemented.

Jaime Savedra, World Bank director for global education, also noted that there was a crisis in education before the epidemic: "It will deepen. It is already more difficult to accelerate and develop learning. We already lived in a world where opportunities were unequal. Now it goes deeper because poor children have fewer opportunities to participate in the educational process.

Here are some highlights from the report:

- School closures due to COVID-19 have left most students on the planet out of school -1.6 billion students at the peak in April 2020. With the opening of schools in some countries in May, that number has dropped to 1.2 billion.

-Before the epidemic, students were completing an average of 11.2 years of schooling throughout their schoolage lives. However, when adjusted for the quality of learning, that amounted to only 7.9 years of schooling. According to Simulating COVID-19 impacts on learning and schooling outcomes: A set of global estimates, 5 months of school closures due to COVID-19 will result in an immediate loss of 0.6 years of schooling adjusted for quality

In the absence of effective compensatory action, school closures lasting 5 months and the unfolding economic shock could result, on average, in a reduction of $\$ 872$ in yearly earnings for each student from today's cohort in primary and secondary school. This is equivalent to approximately $\$ 16,000$ of lost earnings over a student's lifetime, at present value.

Loss of learning, low education levels, wasted time for enrollment and the possibility of dropping out of school can lead to a loss of $\$ 10$ trillion over time to the global economy.

- School closures will impact learning across the system. In the case of lower secondary students, the share of students that do not attain the minimum competencies can increase from $40 \%$ to $50 \%$ because of the immediate shocks.

- Due to the shock caused by the epidemic of income, about 7 million students may drop out of primary and secondary education. This number may increase.

Staying out of school and lower incomes can make people with disabilities, outside of groups, especially girls, vulnerable, which increases isolation and inequality.

- Prior to the outbreak of the global coronavirus pandemic, the world was already struggling with a learning crisis, with 53 percent of children in low- and middle-income countries living in Learning Poverty being unable to read and understand a simple text by age 10 .

- There are two negative effects of children who don't go to school:

- They have no opportunity to learn.

- They forget what they have learned.

\section{DISCUSSION OF THE RESULTS}

More than 1.5 billion students worldwide are out of school due to the COVID-19 pandemic, according to the United Nations Committee on Science and Education (UNESCO) and the World Bank. Although many countries have switched to online / distance learning to avoid an education pandemic, developing countries cannot use this form of education. UNESCO Director-General Audre Azoulay, in an interview with Le Journal du Dimanche, said that $53 \%$ of children and adolescents worldwide do not have a computer at home, and $47 \%$ do not have access to the Internet ( $80 \%$ in Africa), so they cannot use online learning ... Audrey Azoulay stressed that the COVID-19 crisis is forcing a review of the parameters and goals of UNESCO's quality education program. According to her, "the suspension of classes in schools and universities during the pandemic will exacerbate the existing backwardness in fulfilling the UN commitments to ensure universal education by 2030". It is worth using this period to revise our ambitious goals in the field of education, to rethink its future.

It is difficult to predict how serious the consequences will be for the development of higher education around the world. After the pandemic, will universities use the potential of online learning more systematically? Will universities begin to adapt innovative approaches to teaching, which until recently were the prerogative of a small group of leading Western universities? Will the pandemic lead to a change in the established approaches, tools, and methods of assessing knowledge? How will the pandemic affect the internationalization of universities, international educational and scientific cooperation? The next six months will be a test for the leaderships of countries and universities - how quickly and effectively they can cope with the current crisis and provide highquality education.

\section{CONCLUSION}

In general, the COVID-19 pandemic has caused the need to revise the content and format of education during the crisis. This crisis has exacerbated the specifics of $21 \mathrm{st}$ century education and made distance learning necessary. In many countries, the possibility of using distance education is already being seriously discussed. Former UK Universities, Science, Research and Innovation Minister Joe Johnson said the move to online learning could help 
the UK open up to global markets. Universities should capitalize on this crisis by building on the online learning experience. By moving to distance learning, UK universities can reap economic benefits in the long term by offering students more online courses. The current situation will allow British universities to reach a higher level. It has been a necessary process for higher education institutions to move faster to deliver materials digitally and online. It is necessary to use this crisis in light of how distance education is provided, how it will develop and expand.

\section{REFERENCES}

[1] R. Davidson, J.G. Mackinnon, Estimation and Inference in Econometrics, Oxford: Oxford University Press., 1993.

[2] D. Dickey, W. Fuller, Likelihood Ratio Statistics for Autoregressive Time Series with a Unit Root, Econometrica: J.of the Econometric Society, 49(4) (1981) 1057-1072.

[3] M. Falk, R\&D spending in the high-tech sector and economic growth", Research in Economics, 61 (2007) $140-147$.

[4] Institutional Settings and the Source of Funds of R\&D Matter? Oxford Bulletin of Econ. and Statistics 66(3) (2004) 353-378.

[5] J.V. Hasanova, The transformation of human needs in the digital economy, AEBMR-Advances in Economics Business and Management Research, T: 81 pp. 753-756.

[6] C. I. Jones, J. C. ve Williams, Too Much of a Good Thing? The Economics of Investment in R\&D, J.of Econ. Growth 5 (1) (2000) 65-85.

[7] A. Jalil , M. ve Syed, Environment Kuznets curve for CO2 emissions: A cointegration analysis for China, Energy Policy 37 (2009) 5167-5172.

[8] R\&D, Patents and Productivity, Chicago of University Press, Chicago, 1984.

[9] M. Verbic, B. Majcen, M. Cok, R\&D and Economic Growth in Slovenia: A Dynamic General Equilibrium Approach with Endogenous Growth, Munich Personal RePEc Archive, (2009) 17819.

[10] C. R. Nelson, C. R. Plosser, Trends and Random Walks in Macroeconmic Time Series, J. of Monetary Econ. 10(2) (1982) 139-162. http://doi.org/10.1016/0304-3932(82)90012-5
[11] P. C. B. Phillips, P. Berron, Testing for a Unit Root in Time Series Regression. Biometrika 75(2) (1988) 335-346.

[12] A.J. Samimi, S.M. ve Alerasoul, R\&D and Economic Growth: New Evidence from Some Developing Countries, Australian J. of Basic and Applied Sci. 3(4) (2009) 3464-3469.

[13] B. Samimi, ICT and Economic Growth: New Evidence from Some Developing Countries Australian, J. of Basic and Applied Sci. 4(8) (2010) 3086-3091.

[14] D. Shefer, A. ve Frenkel, R\&D, Firm Size and Innovation: An Empirical Analysis, Technovation 25 (1) (2005) 25-32.

[15] Eric C. Wang, R\&D Efficiency and Economic Performance: A Cross-Country Analysis Using The Stochastic Frontier Approach, J. of Policy Modeling 29 (2) (2007) 345-360.

[16] M. Zachariadis, R\&D-induced Growth in the OECD?" Review of Development Economics 8(3) (2004) 423-439. 